\title{
Modification of chlorine dioxide bleaching of Gmelina arborea (gamar) pulp
}

\author{
M. Sarwar Jahan ${ }^{1 *}$, M. M. Uddin ${ }^{2}$ and M. A. Kashem ${ }^{3}$ \\ ${ }^{1}$ Pulp and Paper Research Division, BCSIR Laboratories, Dhaka, Dr. Qudrat-i-Khuda Road, Dhaka 1205, Bangladesh \\ ${ }^{2}$ Department of Chemistry, Dhaka College, National University, Dhaka-1205, Bangladesh \\ ${ }^{3}$ Physical Instrumentation Division, BCSIR Laboratories, Dhaka, Dr. Qudrat-i-Khuda Road, Dhaka 1205, Bangladesh
}

\begin{abstract}
Elemental Chlorine Free (ECF) pulp bleaching is now the dominant pulp bleaching process in globally. In most bleachery, chlorine dioxide is over-consumed. About two thirds of the chlorine dioxide is wasted in useless side reactions. In the study, kraft pulp from Gmelina arborea (gamar wood) was bleached by ECF bleaching in modified sequences. Oxygen prebleaching was carried out to decrease $\mathrm{ClO}_{2}$ requirement, which reduced kappa number of kraft pulp by $47.6 \%$ and increased pulp brightness by 21.7 percent points. Several sequences were tested based on the application of limited charges of $\mathrm{ClO}_{2}$ during successive $\mathrm{ClO}_{2}$ and extraction stage. Application of this concept allowed a $33 \%$ reduction of $\mathrm{ClO}_{2}$ to reach target brightness. The kraft pulp could not reach target brightness of $80 \%$ in $\mathrm{DED}$ sequences using even $30 \mathrm{~kg} \mathrm{ClO}{ }_{2}$ /ton of pulp, while splitting of same amount of $\mathrm{ClO}_{2}$ charge into DEDED sequences reached the pulp brightness to $81.1 \%$. But oxygen delignified kaft pulp reached $79.6 \%$ brightness using $25 \mathrm{~kg} \mathrm{ClO}_{2} /$ ton of pulp in DED sequences. In the splitting of $\mathrm{ClO}_{2}$ charge into DEDED sequences, Oxygen pulp reached to $85 \%$ brightness by using only $20 \mathrm{~kg} \mathrm{ClO}_{2}$ /ton pulp.
\end{abstract}

Keywords: Pulp bleaching; Gmelina arborea (gamar); Chlorine dioxide; Chlorine dioxide Splitting and Brightness

\section{Introduction}

Gmelina arborea (gamar) as the main wood source for pulping in Karnaphuli Paper Mills (KPM), the only pulp mill in Bangladesh, cooked by kraft process. Unfortunately, the brightness of the produced pulp can't meet the consumer demand. Pulping conditions can affect residual lignin nature, which may play a key role in pulp brightness development (Jahan et al., 2007). The bleachability of bamboo pulp was improved when pulping was done with a higher active alkali charge and sulphidity (Jahan et al., 2007).

Chlorine dioxide $\left(\mathrm{ClO}_{2}\right)$ is the dominant chemical pulping process golbally. Oxidation of lignin with $\mathrm{ClO}_{2}$ is the main reaction to reach delignification and brightness target levels. Despite the occurrence of several side reactions it seems that the main mechanism is the ring opening of the free phenolics (Lachenal and Chirat, 1999). In most bleaching mills, chlorine dioxide is over-consumed and the oxidant charge generally applied for delignification is more than twice the theoretical oxidizing power necessary to convert free phenolic groups to soluble oxidized units bearing carboxylic functions (Chirat and Lachenal, 1999; Lachenal and Chirat, 2000). Good results are observed at low $\mathrm{ClO}_{2}$ charge in order to make reactions on free phenolic groups selective and avoid secondary reactions. To avoid secondary reactions, splitting the full chlorine dioxide charge into subdivided stages at low charge is a good option in ECF bleaching (Hamzeh et al., 2007). So, in this study $\mathrm{ClO}_{2}$ charge was splitted into subdivided stages.

To reduce effluent load in Elemental Chlorine Free (ECF), prebleaching have been studied extensively (Ikeda et al., 1999; Jahan et al., 2006, 2013). Oxygen delignification is the most common and environmental friendly process employed prior to ECF and TCF bleaching sequences for continuance of delignification to reduce lignin in pulp by $35-55 \%$ prior to bleaching (Samuelson, 1994). The oxygen delignification modifies residual lignin through increase of carboxyl groups and a decrease in free phenolic groups (Gellerstedt et al., 1986).

In this study, gamar wood chips was cooked by kraft process in mill conditions and the produced pulp was oxygen delignified prior to ECF bleaching. Kraft and oxygen delignified pulps were $\mathrm{ClO}_{2}$ bleached by splitting total $\mathrm{ClO}_{2}$ charge.

\footnotetext{
*Corresponding author e-mail: sarwar2065@yahoo.co.uk
} 
The delignification and brightness after $\mathrm{D}_{0} \mathrm{E}$ in varying $\mathrm{ClO}_{2}$ charge were determined. The final brightness and effluent load after splitted $\mathrm{ClO}_{2}$ charge were also studied.

\section{Materials and methods}

\section{Raw materials}

Gamar wood chips were collected from Karnaphuli Paper Mills (KPM) and cooked by kraft process. The cooking was carried out in thermostatically control digester, rotating at $1 \mathrm{rpm}$. The cooking conditions were $170{ }^{\circ} \mathrm{C}$ for $120 \mathrm{~min}$, liquor to material ratio 4 , active alkali charge $18 \%\left(\right.$ as $\left.\mathrm{Na}_{2} \mathrm{O}\right)$ on oven dried (o.d.) wood basis.

After digestion, pulp was washed until free from residual chemicals, and screened in a flat vibratory screener (Yasuda, Japan). The screened pulp yield, total pulp yield and screened reject were determined gravimetrically as percentage of o.d. raw material. The kappa number (T 236 om-99) of the resulting pulp was determined in accordance with Tappi Test Methods.

\section{Oxygen delignification}

Oxygen delignification (OD) was carried out in thermostatically control digester, rotating at $1 \mathrm{rpm}$. OD conditions were $110{ }^{\circ} \mathrm{C}$, retention time $60 \mathrm{~min}$, pulp consistency $10 \%, \mathrm{NaOH} 2 \%, \mathrm{MgSO}_{4} 0.3 \%$ and $\mathrm{O}_{2}$-pressure $3.5 \mathrm{~kg} \mathrm{~cm}^{-2}$. The kappa number, viscosity and brightness of the resulting pulp was determined in accordance with Tappi Test Methods (T 236 om-99), (T 230 om-99) and (T 452 om-92), respectively.

\section{Bleaching}

Kraft and oxygen delignified pulps were bleached by $\mathrm{D}_{0} \mathrm{E}_{\mathrm{p}} \mathrm{D}_{1}$ and $\mathrm{D}_{0} \mathrm{E}_{\mathrm{p}} \mathrm{D}_{1} \mathrm{ED}_{2}$ bleaching sequence. The $\mathrm{ClO}_{2}$ charge was varied from $0.5 \%$ to $2.5 \%$ and temperature was fixed at $70{ }^{\circ} \mathrm{C}$ for $45 \mathrm{~min}$ in the $\mathrm{D}_{0}$ stage. The $\mathrm{pH}$ was adjusted to get end $\mathrm{pH} 2.5$ by adding dilute $\mathrm{H}_{2} \mathrm{SO}_{4}$. In alkaline extraction stage, temperature was $70{ }^{\circ} \mathrm{C}$ for 120 min and $\mathrm{NaOH}$ and $\mathrm{H}_{2} \mathrm{O}_{2}$ charges were $2 \%$ and $0.5 \%$, respectively. Using same the $\mathrm{ClO}_{2}$ charge, DED sequences were splitted into DEDED sequences. In the final $\mathrm{D}_{1}$ and $\mathrm{D}_{2}$ stage, the $\mathrm{pH}$ was adjusted to get end $\mathrm{pH} 4.5$ and 6.5 , respectively, by adding dilute $\mathrm{NaOH}$ and temperature was $70^{\circ} \mathrm{C}$ for $120 \mathrm{~min}$. The pulp consistency was $10 \%$ in all the stages. The brightness (T 452 om-92) and viscosity (T 230 om-99) of the bleached pulp were determined in accordance with Tappi Test Methods.

\section{Results and discussion}

\section{Oxygen delignification}

The yield of kraft pulp from gamar wood with $18 \%$ active alkali was $48.2 \%$ The kappa number of the pulp was 18.3 and viscosity $16.2 \mathrm{mPa}$.s. Oxygen delignification of the produced pulp was carried out in order to reduce kappa number. The kappa number was reduced by $47.6 \%$, while the overall pulp yield was reduced by 2 percent unit. The degree of oxygen delignification is dependent on initial kappa number $(\mathrm{Vu}$ et al., 2004). $\mathrm{Vu}$ and co-workers showed that pulps with an initial kappa number of 11-22, the degree of delignification was between 44 and 48\%. These results indicated that kraft pulps with a low kappa number could also be readily delignified by oxygen delignification. It is established that the effectiveness of an oxygen delignification stage is limited to $50 \%$ delignification. Beyond this level, severe cellulose degradation takes place, resulting in the deterioration of pulp viscosity and strength characteristics (McDonough, 1996; Masura, 1993). Oxygen delignification of soda-AQ bagasse pulp reduced kappa number by almost 50\% with marginal yield loss (Mohta et al., 1998). Oxygen delignification significantly increased unbleached pulp brightness from $18.3 \%$ to $40.0 \%$ (Table I).

\section{Delignification of $\mathrm{DE}$ in varying $\mathrm{ClO}_{2}$ charges}

Several $\mathrm{D}_{0} \mathrm{E}$ stages at varying $\mathrm{ClO}_{2}$ /pulp charges $(0.5$ to $2.5 \%$ on o.d. pulp) were carried out on the unbleached and oxygen delignified pulp and shown in Table II and Fig. 1. It shows that the kappa number decreased rapidly and linearly up to $1 \% \mathrm{ClO}_{2}$ charge followed by a slower and flattened decreased (Fig. 1). McDonough et al. (2000) also showed that $95 \%$ delignification after $\mathrm{D}_{0} \mathrm{E}$ could be reached in only one minute. This was due to the oxidizing efficiency of $\mathrm{ClO}_{2}$ severely decreases at a higher charge (Hamza et al., 2007). Hamza and co-workers showed the minimum of about $5 \mathrm{eq} / \mathrm{mol}$ of $\mathrm{C}_{9}$ at the lowest $\mathrm{ClO}_{2}$ charge. Above $0.6 \% \mathrm{ClO}_{2}$ charge, the oxidizing power increased and reached $10 \mathrm{eq} / \mathrm{C}_{9}$ at high $\mathrm{ClO}_{2}$ charge. The theoretical value for the formation of muconic acid moieties is $4 \mathrm{eq} / \mathrm{C}_{9}$, which was lower than the $5 \mathrm{eq} / \mathrm{C}_{9}$. This indicates that increasing quantity of $\mathrm{ClO}_{2}$ was consumed by non-useful reactions. It is suggested that $\mathrm{ClO}_{2}$ reacts with already oxidizable lignin mucomic acid structure ( $\mathrm{Ni}$ and Heiningen, 1992). It is believed that when the $\mathrm{ClO}_{2}$ consumption in $\mathrm{D}_{0}$ reaches a certain level, it is beneficial to remove the oxidizable lignin which accumulates and reactive with $\mathrm{ClO}_{2}$. Extraction stage can do it. Therefore, D and E stages were splitted to several stages, which are discussed in later section. 


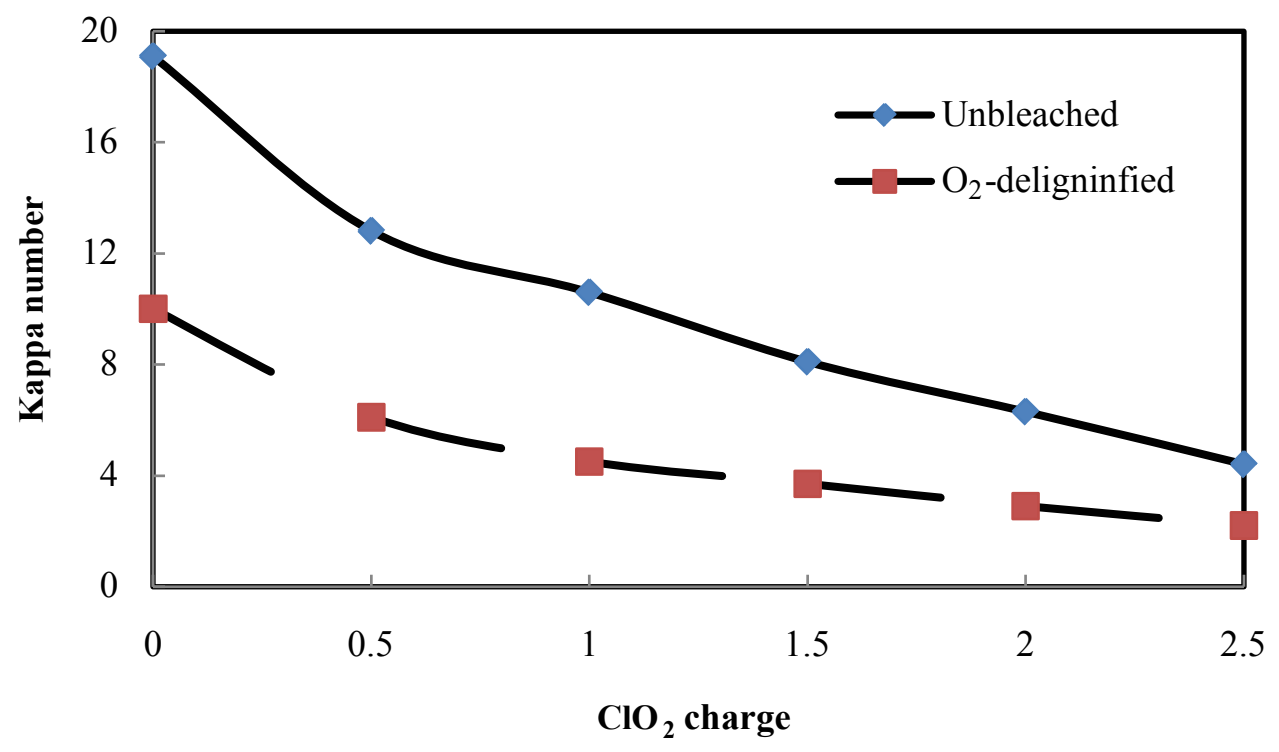

Fig. 1. Effect of chlorine dioxide charge on the $D_{0} E$ stage kappa number

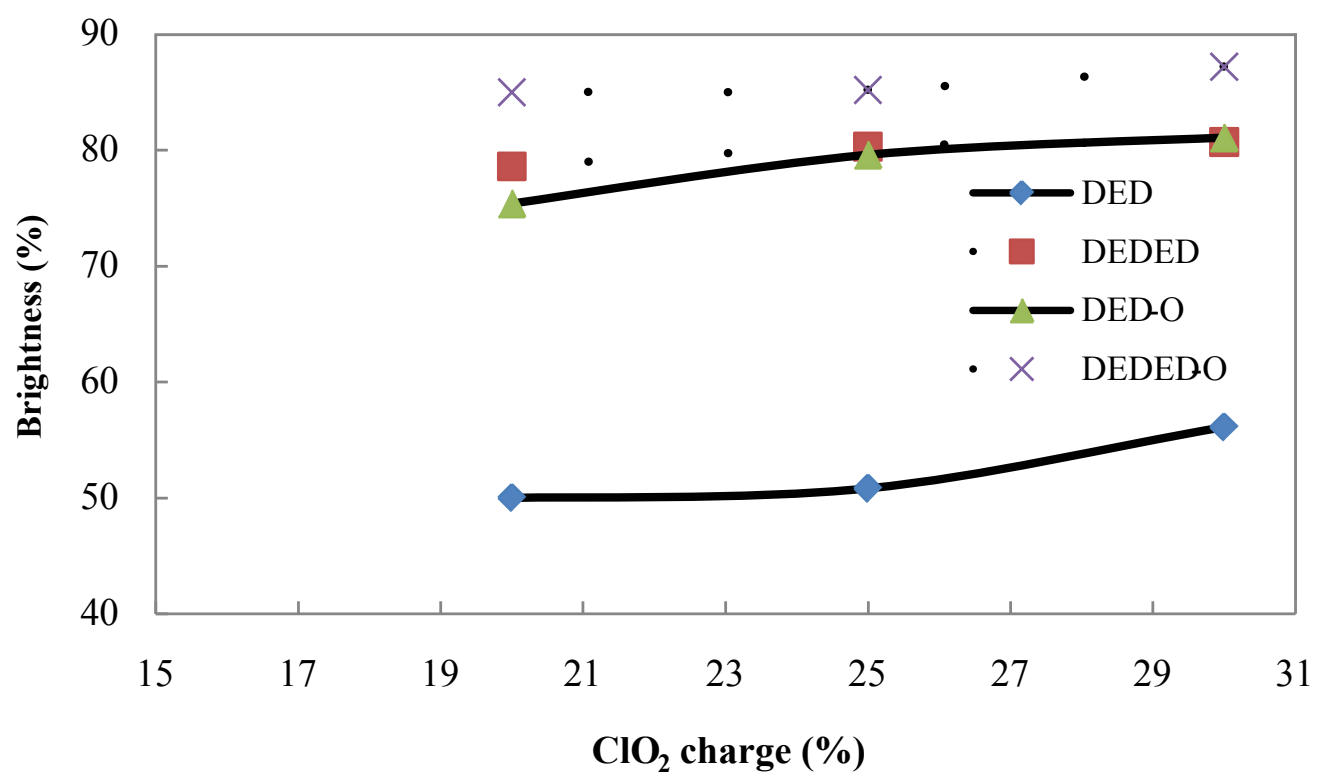

Fig. 2. Final brightness after DED and DEDED sequences of kraft and oxygen delignified pulps

As shown in Table 2, yield after $\mathrm{D}_{0}$ stage was not dependent by $\mathrm{ClO}_{2}$ charge. Both unbleached and oxygen delignified pulp showed around $94 \%$ yield. The pulp viscosity after $\mathrm{D}_{0}$ stage decreased by $12.3 \%$ for unbleached and $35.8 \%$ for oxygen delignified pulp at $0.5 \% \mathrm{ClO}_{2}$ charge. But the viscosity did not decrease with increasing further $\mathrm{ClO}_{2}$ charge. The pulp brightness increased from $21.1 \%$ to $37.3 \%$ for unbleached and $49.5 \%$ to $73.7 \%$ for oxygen delignified pulp with increasing $\mathrm{ClO}_{2}$ charge from $0.5 \%$ to $2.5 \%$.
Splitting of $\mathrm{ClO}_{2}$ charge

Table III shows the advantages obtained by splitting a DED stages into DEDED stages in which one third of the chlorine dioxide was applied three times with intermediate extraction and washing. At the same $\mathrm{ClO}_{2}$ consumption, the splitting process showed higher brightness and similar viscosity. Kraft pulp could not reach the target brightness of $80 \%$ in applied total $\mathrm{ClO}_{2}$ charges in DED bleached sequences. Splitting of 
Table I. Pulping and oxygen delignification of Gamari wood

\begin{tabular}{ccccc}
\hline & Pulp yield (\%) & Kappa number & Brightness (\%) & Viscosity (mPa.s) \\
\hline Kraft & 48.2 & 19.1 & 18.3 & 16.2 \\
$\mathrm{O}_{2}$ - delignification & $95.5(46.0)$ & 10.0 & 40.0 & 12.3 \\
\hline
\end{tabular}

Table II. Effect of $\mathrm{ClO}_{2}$ charge on the pulp properties after $\mathrm{D}_{0} \mathrm{E}$ stage

\begin{tabular}{cccccc}
\hline \multirow{2}{*}{$\begin{array}{c}\mathrm{ClO}_{2} \text { charge } \\
(\%)\end{array}$} & Yield (\%) & $\begin{array}{c}\text { Kappa } \\
\text { number }\end{array}$ & $\begin{array}{c}\text { Viscosity } \\
(\mathrm{mPa} . \mathrm{s})\end{array}$ & $\begin{array}{c}\text { Brightness } \\
(\%)\end{array}$ \\
\hline Unbleached & 0.5 & 94.4 & 12.8 & 14.2 & 21.2 \\
& 1.0 & 94.6 & 10.6 & 15.4 & 22.9 \\
& 1.5 & 94.7 & 8.1 & 15.1 & 25.6 \\
& 2.0 & 94.1 & 6.3 & 15.6 & 29.4 \\
Oxygen & 2.5 & 94.0 & 4.4 & 15.8 & 37.3 \\
delignified & 0.5 & 94.2 & 6.1 & 7.9 & 49.5 \\
& 1.0 & 94.1 & 4.5 & 8.0 & 62.1 \\
& 1.5 & 94.8 & 3.7 & 7.8 & 69.5 \\
& 2.0 & 94.4 & 2.9 & 7.4 & 71.4 \\
& 2.5 & 94.5 & 2.2 & 7.4 & 73.7 \\
\hline
\end{tabular}

Table III. Splitting of DED bleaching stages into DEDED

\begin{tabular}{|c|c|c|c|c|}
\hline & Splitting & $\begin{array}{c}\text { Total } \mathrm{ClO}_{2} \\
\text { charge (kg/MT pulp) }\end{array}$ & $\begin{array}{l}\text { Viscosity } \\
\text { (mPa.s) }\end{array}$ & Brightness (\%) \\
\hline \multirow[t]{6}{*}{ Unbleached } & DED & 30 & 10.1 & 56.1 \\
\hline & & 25 & 10.7 & 50.8 \\
\hline & & 20 & 10.8 & 50.0 \\
\hline & DEDED & 30 & 9.9 & 80.7 \\
\hline & & 25 & 10.5 & 80.3 \\
\hline & & 20 & 10.5 & 78.6 \\
\hline \multirow{6}{*}{$\begin{array}{l}\text { Oxygen } \\
\text { delignified }\end{array}$} & DED & 30 & 4.6 & 81.1 \\
\hline & & 25 & 5.1 & 79.6 \\
\hline & & 20 & 5.4 & 75.4 \\
\hline & DEDED & 30 & 5.4 & 87.2 \\
\hline & & 25 & 5.5 & 85.2 \\
\hline & & 20 & 5.5 & 85.0 \\
\hline
\end{tabular}


DED stages into DEDED stages increased pulp brightness from $51 \%$ to $80 \%$ using $25 \mathrm{~kg} \mathrm{ClO} /$ ton of pulp. Oxygen delignified pulp was easier to brighten as shown in Fig. 2. In the DED bleaching sequences, final pulp brightness reached to $75.4 \%$ using total $\mathrm{ClO}_{2}$ of $20 \mathrm{~kg} /$ ton of pulp; further increase of $\mathrm{ClO}_{2}$ to $30 \mathrm{~kg} /$ ton of pulp increased pulp brightness to $80.7 \%$. But splitting of $\mathrm{ClO}_{2}$ charges, pulp brightness reached to $85 \%$ by using only $20 \mathrm{~kg} /$ ton of pulp. The better delignification and higher brightness were likely the result of removing solubilized lignin by-products, which otherwise would have consumed some $\mathrm{ClO}_{2}$. Similar results were observed elsewhere (Chirat et al., 2000; Jahan et al., 2006). Intermediate alkaline stages should not only extract the $\mathrm{ClO}_{2}$ reaction products but also reactivate the pulp residual lignin by regenerating free phenolic groups (Berry, 1996; McKague et al., 1995).

\section{Conclusions}

Kraft pulp from Gmelina arborea was bleached by ECF bleaching in modified sequences. Oxygen delignification reduced kappa number by $47.6 \%$. $\mathrm{D}_{0} \mathrm{E}$ kappa number decreased rapidly at low $\mathrm{ClO}_{2}$ charge followed by slower decrease, which indicated over consumption of $\mathrm{ClO}_{2}$ by non-useful reactions. Splitting of DED stages into DEDED stages increased pulp brightness from $51 \%$ to $80 \%$ using $25 \mathrm{~kg} \mathrm{ClO}_{2} /$ ton of pulp for kraft pulp. Splitting of $\mathrm{ClO}_{2}$ charges, pulp brightness reached to $85 \%$ by using only $20 \mathrm{~kg} /$ ton of pulp only for oxygen delignified pulp. Splitting of $\mathrm{ClO}_{2}$ charge, reduced over consumption of $\mathrm{ClO}_{2}$ through removing solubilized lignin by-products (like mucomic acid) resulted better delignification and higher brightness of the bleached pulp.

\section{Acknowledgement}

The authors wish to thank BCSIR Laboratories, Dhaka, for providing the necessary funds to carry out this research.

\section{References}

Berry R (1996), (Oxidative) Alkaline extraction In: Pulp Bleaching, Principles and Practice, Eds. Dence CW and Reeve DW, Tappi press, Atlanta, p 293.

Chirat C, Lachenal $\mathrm{M}$ and Mortha $\mathrm{G}$ (2000), $\mathrm{ClO}_{2}$ splitting in chlorine dioxide delignification, Tappi pulping conf. Proc., Tappi Press, Atlanta Ga.
Chirat C and Lachenal D (1999), Chlorine dioxide bleaching gets the once over from, Pulp Pap. Int. 41(10): 41.

Gellerstedt G, Gustafsson K and Lindfors EL (1986), Structural changes in lignin during oxygen bleaching, Nordic Pulp and Paper Research Journal 1(3): 14-17.

Hamzeh Y, Bénattar N, Mortha G and Calais C (2007), Modified ECF Bleaching Sequences Optimizing the Use of Chlorinedioxide, Appita Journal 60(2): 150.

Ikeda T, Hosoya S, Tomimura Y, Magara K and Takano I (1999), Sulfuric acid bleaching of kraft pulp I: bleaching of hardwood and softwood kraft pulps, $J$ Wood Sci. 45: 233-237.

Jahan MS, Chowdhury DN, Islam MK and Ahmed FN (2006), Elemental chlorine free and total chlorine free bleaching of soda-AQ cotton stalks pulps, J Asiatic Soc Bangladesh 32: 179-186.

Jahan MS, Rubaiyat A and Sabina R (2007), Influence of cooking conditions on pulp properties in kraft pulping, Japan Tappi J 61(11): 1307-1373.

Jahan MS, Hosen MM and Rahman MM (2013), Comparative study on the prebleaching of bamboo and hardwood pulps produced in Karnaphuli Paper Mills, Turkish Journal of Agriculture and Forestry 37(6): 812-817.

Lachenal D and Chirat C (2000), Improvement of $\mathrm{ClO}_{2}$ delignification in ECF bleaching, Proc. Int. Pulp Bleaching Conf., Halifax, p 159.

Lachenal D and Chirat C (1999), About the efficiency of the most common bleaching agents, Tappi Pulping Conference Proc., vol. 2, Orlando, pp 623-630.

Masura V (1993), Delignification and degradation of kraft pulp during oxygen bleaching, Cellul Chem Technol. 27: 201-215.

McDonough TJ (1996), Oxygen delignification In: Pulp Bleaching, Principles and Practice, Eds. Dence CW and Reeve DW, Tappi Press, Atlanta, pp 213-239.

McDonough TJ, Courchene CE and Baromès JC (2000), Rapid DO and simplified bleaching for low capital, low AOX, and low chemical, Proc. Int. Pulp Bleaching Conf., Halifax, p 151. 
McKague AB, Reeve DW and Xi F (1995), Reaction of lignin model compounds sequentially with chlorine dioxide and sodium hydroxide, Nordic Pulp and Paper Research Journal.

Mohta D, Upadhaya JS, Kapoor SK, Roy AK and Roy DN (1998), Oxygen delignification of soda and soda-AQ bagasse pulps, Tappi $J$ 81(6): 184-187.

Ni Y and A van Heiningen (1992), Delignification mechanism of chlorine dioxide bleaching of kraft pulp, $2^{\text {nd }}$ Europian Workshop on Lignocellulosics and Pulp, Grenoble, CTP proceedings, pp 85-86.
Samuelson OH and Ojteg UO (1994), Optimized oxygen bleaching of kraft pulp treated with nitrogen dioxide, Tappi J 77(11): 127-133.

Vu TH M, Pakkanen H and Alén R (2004), Delignification of bamboo (Bambusa procera acher): Part 1. Kraft pulping and the subsequent oxygen delignification to pulp with a low kappa number, Industrial Crops and Products 19(1): 49-57

Received: 23 April 2017; Revised: 02 May 2017;

Accepted: 29 May 2017. 